\title{
Reporting Peace Negotiations: Content and Tactics from Uganda's Dailies
}

\section{Charles Martin Jjuuko*}

Development and Communications Specialist, Kisumu, Kenya

\begin{abstract}
The media in Uganda face various challenges in their development path although information about this reality is not fully or properly documented. The area of peace journalism is not an exception. Uganda suffered from civil strife, especially armed conflict, between 1966 and 2008. This paper attempts to analyse the representation of peace and armed conflict issues from a peace journalism perspective through a critical assessment of the content published by Uganda's dailies during the peace negotiations between the Government of Uganda and the Lord's Resistance Army between 2006 and 2008. It concludes that the two main negotiating parties as well as the analysed media engaged in some level of manipulation to, on the one hand, get their preferred points of view published and, on the other, to guarantee access to key sources of information.
\end{abstract}

Keywords: Government of Uganda; Human Rights; International Criminal Court; Juba peace process; Lord's Resistance Army; Peace Journalism

\section{Introduction}

In the short history of Uganda, the media has been one of the most important modes of communication next to word-of-mouth, while the newspapers have offered important sketches through which the country's history can be traced. Using news and opinions contents on the 2006-2008 peace negotiations between the Government of Uganda and the Lord's Resistance Army, this paper offers a collection, collation and analysis of content published by two mainstream Uganda daily newspapers between 1st January and 31st December 2007, Daily Monitor and The New Vision, combined with results from keyinformant interviews to assess the health-if at all-of peace journalism and related media practices in Uganda. It is important to note that the research used to complete this paper considered the frame of peaceand conflict-reporting, with the term 'conflict' limited to refer to 'armed conflict' only.

Between 1988 and 2008, Northern Uganda suffered at the hands of a war waged by the Lord's Resistance Army (LRA), an insurgent group led by Mr. Joseph Kony, against the Government of Uganda, causing the deaths of thousands of civilians and displacing over 1.5 million of them.

Uganda, in December 2003, referred the situation in Northern Uganda to the International Criminal Court (ICC) [1] and in 2005after two years of investigations-the ICC Prosecutor, Mr. Louis Moreno-Ocampo, issued warrants of arrest for five top commanders of the LRA on various counts of war crimes and crimes against humanity [1]. Instead of allowing the wanted commanders to surrender, the LRA sought to engage in peace talks with the Government of Uganda, a process that commenced in July 2006. This particular peace process, brokered by the Government of South Sudan, continued to the end of 2008-to no clear conclusion up.

Throughout the peace process, the LRA seemingly sought to avoid the arrest of their top commanders by demanding that the ICC arrest warrants be nullified before a comprehensive peace agreement could be signed and implemented. Through a well-orchestrated propaganda campaign, the LRA utilised local and international media space to portray the ICC arrest warrants as the biggest obstacle in the search for peace in Northern Uganda.

Following the beginning of the peace process in July 2006, a major debate about peace and justice ensued on Uganda's airwaves and in the mainstream print media outlets, responding to a simple (if not oversimplified) question: "Peace or Justice: what should come first?" This debate, as well as the questions that it has evoked about media's function in times of conflict, provided the inspiration behind this research.

Overall, the research was meant to build on existing peace journalism literature and assess the application-if at all-of its practices in the Ugandan situation.

The New Vision and Daily Monitor were chosen because they were the biggest mainstream dailies, in circulation and readership terms, in Uganda at the time of the research.

\section{Literature Review}

An assessment of the concept of peace journalism is considered a powerful means of providing a firm foundation to understanding the tactics that inform the utilisation of mainstream newspaper space on peace and armed conflict matters in Uganda. A concise look at the development and practice of peace journalism in different parts of the world in recent times is, therefore, prudent. Ultimately, this section provides links between earlier pieces of research to the findings; discussion; and, conclusions of this research.

In times of conflict, especially armed conflict, various realities on the ground-including "patriotism, national interest, anger, censorship and propaganda" - have the potential to conspire against objective reporting [2]. The argument that, in times of conflict, the media ought to promote "peace rather than war ... tolerance rather than hatred" remains one of the drivers behind the concept of peace journalism [3]. Reporting armed conflict has historically been conducted from a sense of its 'news value', although it has also been done mindful of its

${ }^{*}$ Corresponding author: Charles Martin Jjuuko, Development and Communications Specialist, Kisumu, Kenya, E-mail: cmjjuuko@gmail.com

Received August 27, 2012; Accepted November 29, 2012; Published December 07, 2012

Citation: Jjuuko CM (2012) Reporting Peace Negotiations: Content and Tactics from Uganda's Dailies. J Mass Commun Journalism 2:134. doi:10.4172/21657912.1000134

Copyright: @ 2012 Jjuuko CM. This is an open-access article distributed under the terms of the Creative Commons Attribution License, which permits unrestricted use, distribution, and reproduction in any medium, provided the original author and source are credited. 
potential to increase 'circulations and ratings' [2]. In recent decades, a school of thought has emerged urging journalists to spread the culture of peace in conflicts' stead.

'Peace journalism' is an idea that has been bolstered by the explorations of the likes of Johan Galtung's conflict and peace issues [4] with a vision which deliberately fronts for stories that promote peace at the expense of those with the potential of escalating conflict [2]. One of the most immediate challenges of peace journalism is its non-conventional approach to coverage of conflict situations. Lee and Maslog [2] aptly state thus:

At first glance, peace journalism runs counter to the time-honored journalistic principle of objectivity that sees the journalist as a detached and unbiased mirror of reality. According to Iggers: "Although few journalists still defend objectivity, it remains one of the greatest obstacles to their playing a more responsible and constructive role in public life" (p.91). As such, responsible journalism should be about intervention, as McGoldrick and Lynch argued: "The choice is about the ethics of that intervention-therefore the question becomes 'what can I do with my intervention to enhance the prospects for peace'?"

By these facts, it is safe to agree that peace journalism challenges the role of objectivity in reporting, an issue that has always remained central to mainstream journalism practices.

\section{Methodology}

Firstly, for content analysis, the researcher used the allAfrica. com search engine [5], employing phrases like "human rights", "Juba peace talks", "International Criminal Court", and "Lord's Resistance Army" to locate the relevant news, op-ed and editorial opinion stories about the peace process. Dearing and Rogers [6] have argued that: "Content analysis is the quantification of meaning in documents. Meaning may be both manifest (that is, obvious) or latent (implied or inferred). A content analyst develops different measurement procedures depending on the type of meaning to be measured." But perhaps the most pointed definition of content analysis, adopted for this research comes from Berelson [7] who asserts content analysis is: "A research for the objective systematic and quantitative description of the manifest content of communication." For this research, content analysis was employed to compare the obvious quantitative evidence in stories on the Northern Uganda peace process. The ultimate purpose of employing content analysis was to use statistics to make what Deacon et al. [7] refers to as the 'broader inferences about the processes and politics of representation'.

Secondly, key-informant interviews were utilised to derive answers from senior journalists working with Uganda's dailies in order to bolster the meaning derived from the content analysis. The use of this approach in tandem with the quantitative method was based on the strengths offered by interpretive research tools, especially the room for "dialogue" as opposed to the "detachment" that comes with empirical research [7].

Whereas the analysis of content provided the foundation upon which this research was built, in-depth interviews were the pillars upon which proper context to the media content and tactics was provided. Similar to Firmstone and Statham [8], content analysis was applied in the knowledge 'that newspaper coverage is not an undistorted and completed mirror of reality.' Given that the content analysis was meant to understand the reasons behind media content and tactics on peace issues in Ugandan newspapers, the inferences derived from in-depth interviews with the selected senior New Vision and Daily Monitor journalists contributes to the closure of gaps and the validity of the research's findings.

\section{Findings}

The findings and discussion in this section were derived from a combination of content analysis from Daily Monitor and The New Vision and key informant in-depth interviews as means to provide answers to the primary question of this research and draw meaningful conclusions. Key informant interviewees (code-named Respondents 1, 2, 3, 4, 5, 6 and 7) with direct involvement in the writing, reporting, editing and publication of stories on the ongoing peace process were selected for interviews for this research. They all possessed graduate academic grounding in journalism, political science and other specialities related to their work in the media while three of them were pursuing postgraduate studies in a manner that falls in line with what Mwesige [9] has rightly called "the importance attached to formal education" in the realm of Uganda's media.

In the period assessed for this research, Daily Monitor and The New Vision published 91 stories that were within the remit of this research. Of these, Daily Monitor carried the majority of stories with a total of 61 (67\%) compared to The New Vision which published 30 (33\%) of the stories analysed. Respondents interviewed offered varying views about the large variation between the stories published on such subject of concern in the two dailies. One point that featured highly in the responses was the claim that Daily Monitor offered far more attention to stories of human rights concern than The New Vision. Respondent 2 argued that the Daily Monitor had maintained the tradition of covering conflict and human rights issues "for so long, writing and exposing problems in Northern Uganda" during the LRA war that it was only prudent to provide more coverage than The New Vision when it came to the ongoing peace process.

On the whole, the quarterly distribution of stories in both Daily Monitor and The New Vision pointed to a progressive increase during the year 2007 for both newspapers. Daily Monitor's coverage increased from 10 stories in the first quarter to 16 during the second quarter, 18 during the third quarter and 24 in the final quarter. The New Vision, on the other hand, had five stories in the first quarter, seven in the second quarter, and nine in both the third and fourth quarters (Figures 1 and 2).

The apparent progressive increase in the quarterly coverage offered to the Juba peace process is a reflection of the actual pace and the number of publicly acknowledged activities of the negotiating parties during 2007. However, the respondents also alluded to the long spells of silence by the negotiating parties, many times waiting to learn (through the media) what the other party to the negotiations was up

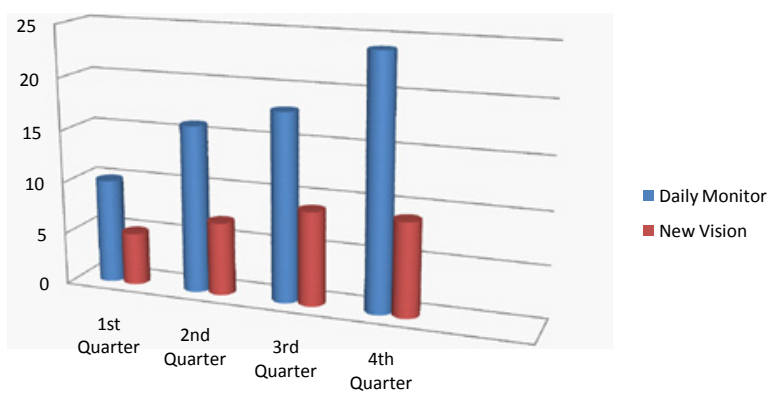

Figure 1: 2007 Quarterly Distribution of Stories. 


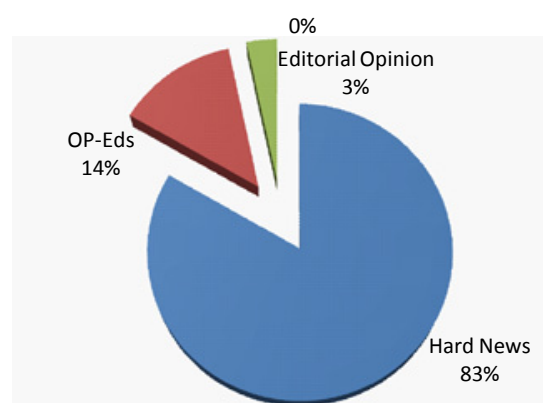

Figure 2: Percentage Share of News, Opinion and Editorial Opinion in Daily Monitor and The New Vision.

to, as a contributory factor amount of news content generated and published. As Respondent 3 states:

Sometimes the delegation would not be in touch for weeks but had interest in knowing what was going on in the other camp. In such cases, they would both wait for the newspapers from Uganda to arrive in Juba South Sudan to know what had transpired or what our thoughts were about either party. This way, the media role in the peace process became much more interesting. (Interviewed in Kampala on 20 March 2008).

The realisation that negotiating parties were keen to be projected or project themselves as keen promoters of peace, could have had a serious bearing to what Tehranian [3] has called the necessity of the media to work for "peace rather than war...tolerance rather than hatred".

In addition, the findings pointed to an urge from the Government of Uganda to limit the number of stories that offered the LRA rebels equitable space for their point of view the Ugandan media. This effort too perhaps translated in some measure of self-censorship from Daily Monitor and The New Vision. As Respondent 3 states:

At the beginning government used to wonder why we gave the LRA a lot media space. From the beginning of the peace process, we faced pressure. Government initially did not accept the other party as equal negotiators. It felt that all these individuals were going to show up and vanish quickly; that they were mere thugs. But when the real issues came up, the other party said: 'You must listen to us. We must negotiate.' (Interviewed in Kampala on 20 March 2008).

Respondent 6 admitted that there were: "people who feel that we have not given government enough space. There are people in government who complain when we give coverage to the rebels." However, this respondent also expressed confidence that the media had stood its ground in maintaining objectivity in its work through explaining to all negotiating parties that the media did not have any obligation to project either of them in good light.

Hard news was the biggest consumer of space in the coverage of the Juba peace process, with a total of $83 \%$ of the stories analysed. It was followed by OP-EDs $14 \%$ and editorial opinions at $3 \%$ of the entire coverage. Whereas it is not surprising that hard news took up the majority of newspaper space, news analyses were negligible. Several reasons could explain this fact but the most pointed one came from Respondent 7, who stated thus:

Often times what is called news analysis in this country is simply the opinion of the writers. That can be dangerous. My newspaper has had a record as an objective, middle-of-the-road paper. We bring out the issues without trying, necessarily, to make any interpretations for our readers. We tend to give information so that the reader can make his or her conclusions... It is important to inform readers, for instance, that while the peace talks continue, the LRA rebels have yet to assemble at agreed assembly points or that they are grumbling about money (Interviewed in Kampala on 21 March 2008) (Figure 3).

All respondents pointed to the fact that hard news provided the best bargain the media to maintain a semblance of neutrality in the coverage of the peace process.

The stories that were within the parameters of this research had a sum of 1,219 paragraphs. Of these, the first quarter of coverage by Daily Monitor and The New Vision accounted for a total of 177 paragraphs (14.52\%) of content, whereas there was a progressive increase in content in the second quarter to 206 paragraphs (16.9\%). The third and fourth quarters had 385 (31.58\%) and 451paragraphs (37\%) respectively.

As already indicated, the progressive increase in content on the Juba peace process was perhaps in direct correlation to the level of activity in the negotiation process. There was a slow start to negotiations in 2007 as both parties jostled and positioned themselves in a manner that made any serious discussions difficult to attain. Besides, as Respondent 1 clearly attests, there was "a deliberate decision to encourage parties to the devastating conflict" to continue with dialogue, meaning that any jostling and struggles between the warring parties during the first quarter of 2007 was "downplayed" by the mainstream newspapers (Interview in Kampala on 18 March 2008). This tactic is a direct echo of the projection of peace journalism as a promoter of peace at the expense of space for ideas that could escalate conflict [2].

\section{Discussion}

Content in the stories analysed was categorised in four thematic bundles of content: general backgrounders; consequences of war; political actors' claims; the Lord's Resistance Army claims; as well as other leaders' claims, bundling the claims of United Nations, donors, Internally Displaced Persons, religious and traditional leaders claims; Human Rights Groups claims; peace deal specifics; justice/victims representation; as well as representations completely unrelated to the peace process.

Thematically, general backgrounders about the conflict between the Government of Uganda and the LRA were the most utilised content in the coverage of the subject in question with a total of 364 paragraphs (29.9\%), whereas consequences of war as a theme attracted a miserly 17 paragraphs (1.4\%). The theme of justice/victims issues, covering the representation of victims' voices and affairs was represented in 202 paragraphs (16.57\%) whereas the voices of human rights groups-

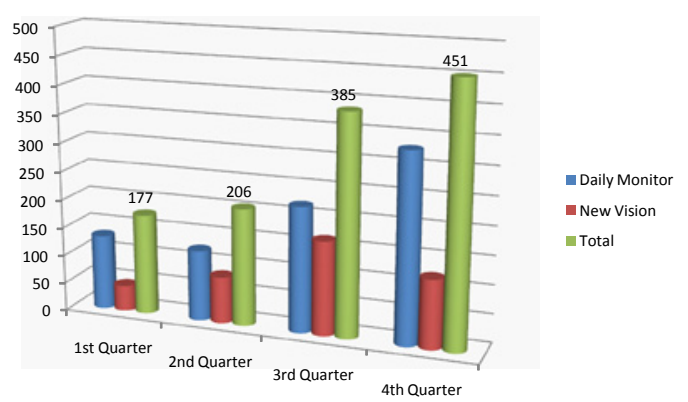

Figure 3: Quarterly Distribution of Total Paragraphs Analysed=1,219 Paragraphs. 
campaigning for a more comprehensive inclusion of victims' issues in the peace process-received only 25 paragraphs $(2.05 \%)$ of availed space from both Daily Monitor and The New Vision.

Claims by political actors-government ministers, officials and military spokespersons-ook up the larger share of content in 2007, with their claims accounting for 155 paragraphs (12.7\%) whereas claims other leaders-United Nations envoys and officials, Internally Displaced People's camp leaders, religious heads and the traditional leaders of Northern Uganda-in all were represented in only 112 paragraphs $(9.18 \%)$. Unlike years of miserly space for its claims in the mainstream and other media, LRA claims accounted for 113 paragraphs $(9.26 \%)$ of space in both Daily Monitor and The New Vision-accounting for the same amount of space that was provided for claims from 'other leaders' (UN, donors, as well as IDPs, religious and traditional leaders) combined. A point worth noting is that the debate on the actual ingredients in the draft 'peace deal' under discussion was represented in only 21 paragraphs $(1.72 \%)$, while the debate on the gruesome consequences of war was represented in only 17 paragraphs (1.4\%).

Respondents interviewed had varying reasons as to why the consequences of war-rape, torture, death, destruction of property-were not as arduously represented as the representation of the demands of the negotiating parties. However, Respondent 1 fronted "advocacy and peace" as the fundamental issues that guided his decisions on selecting content, arguing thus:

There were things that happened and you found yourself in the middle of a judgement call: "What am I supposed to do? Am I supposed to let this pass? Will I be concealing information? Will I be helping someone out there or will I serve a purpose of informing the public, if I publish this?" A case in point was when the LRA camp got into trouble. We got a lot of information about LRA killings of their own senior commanders. If a government person told you: "You know what? LRA is in trouble; they have killed the second-in-command, Mr. Vincent Otti." Really, this information is from sources that definitely would want this published. Because I didn't have concrete corroboration, if the story was wrong, I could have wreaked the peace process. I opted to ignore it although it later turned out to be true.

Another factor that was not sufficiently represented in the content of the stories in question was the apparent continued brutality and abduction of civilians by the LRA in the areas they traversed in parts of DR Congo, Chad and the Sudan. Respondent 1 gave an example of an incident his newspaper chose not to publish despite credible information on the LRA atrocities:

I got reports in December 2007 that LRA had asked for 200 jerrycans. I told myself that this was not a good sign because the LRA does not fetch water. LRA uses jerry-cans to transport bullets and food. I thought something was going wrong; that the whole peace process may not work. Someone was preparing for something we didn't know.

In the end, the LRA moved some of its forces from its hideouts in DR Congo to Chad. This act attracted concrete media attention of Daily Monitor and The New Vision in March 2008, when it occurred, as opposed to December when some media practitioners got wound of the plan but apparently chose not to publish it on precautionary grounds.

Political actor's claims dominated both hard news and opinion space. With $12.7 \%$ of space of the entire coverage, this evidence points to a somewhat high dependence on official sources for content during the peace process. However, unlike coverage during the years of active combat (1988 to 2005)-where little or no content was published with the rebels' point of view-the LRA spokespersons enjoyed an equal amount of space with government spokespersons in 2007. The fact that LRA claims accounted for $9.26 \%$ of space dedicated to the Juba peace process was a landmark shift in the groups' representation by Uganda's dailies. Several complex reasons could be advanced for this occurrence although the respondents offered a narrower perspective. Two prominent reasons fronted by the senior journalists interviewed included the mystique nature of the LRA leader and the lack of media access to him over the years left Ugandan readership yearning for the LRA's point of view. Respondent 5, for instance, stated:

The LRA leader, Joseph Kony, is a person who had been said to be unapproachable; who had mood swings; who is thought to have sacrificed children. Our maiden encounter with him and the ensuing story seemed to quench that thirst of our readers about the desire of knowing what led him to fight the government; what he had achieved; his possible collaborators. We exposed very many issues (Interviewed in Kampala on 19 March 2008).

Another aspect that influenced newsroom decisions on choice of content was the progressively increasing desire by the LRA to provide the media with information about its negotiating positions. Respondent 3 , for instance, gave a terse explanation:

The LRA was more willing to provide information than the government. The complaint then came that we were giving more space to the LRA. Of course, the position of the LRA prior to the peace negotiations was not known. People were interested in the new positions and ever changing positions of the LRA. Secondly, the LRA had eloquent speakers who knew the implications of what was published in the media. At the beginning, the government side did not have similar zeal. The head of the government delegation Internal Affairs minister, Dr. Ruhakana Rugunda would always say: "Things are continuing smoothly; everything is on course." This is the statement he would give most regularly (Interviewed in Kampala on 20 March 2008).

The latter explanation gives credence to the thoughts shared by all respondents that government's public information machinery only woke to the reality of the apparent major role of the media in the dynamics of the peace process much later, a fact that eventually allowed government claims to carry only a slight edge (12.7\%) over LRA claims (9.26\%).

The limited coverage offered to the other claims $(9.18 \%)$ and human rights claims (2.05\%) evoked similarities with what Lee and Maslog [2] have called "little focus on ordinary people" by journalists attempting to practice peace journalism. The players in these two categorieshuman rights groups; the United Nations and its agencies; Uganda's donors; religious leaders; traditional leaders; and IDP camp leadersad played a historically fundamental role in ensuring the survival the communities most affected by the conflict in Northern Uganda. It is partly due to the relentless calls by these groups for genuine dialogue between the Government and the LRA (International Crisis Group 2004; Amnesty International 1999) that provided enabling conditions and support for the ongoing peace process to commence and stay on course. The fact that their claims attracted only a combined $11.23 \%$ of mainstream newspaper coverage represents a sharp imbalance in representation compared to all important actors in the peace process. The respondents did not provide clear-cut responses behind this apparent miserly representation. Respondent 2 acknowledged that 
the "biggest pre-occupation of Northern Ugandans" was the "attempt to rebuild their lives" and that the news media had felt the need to publicise this fact. However, the respondent did not volunteer any clear reasons to explain the limited representation of claims from civic groups working in Northern Uganda during the peace process.

The representation of justice/victims issues in the media was another theme of concern in the mainstream news media, accounting for $16.57 \%$ of content on the peace process. Earlier in the process, serious concerns had been raised by human rights groups that neither the negotiating parties nor the news media had taken interest in the actual interests of victims of the conflict in Northern Uganda as well as their desire to have the perpetrators of crimes to face justice. In 2007, however, there was a progressive increase in content on matters of justice and victims' concerns. Notwithstanding this fact, the news media seemed to have accepted the emerging idea that international justice was the most serious hurdle to the process, thus devoting most justice/victims representation space to content that castigated the role of the International Criminal Court (ICC) in the Northern Uganda situation as the greatest liability to any peace efforts [1].

Although the Court reached out to, and shared information with, various media houses in Uganda, the journalists conceded that understanding the complex operations of the new international Court had been a challenge that was taking them some time to digest. As Respondent 4 suggests:

The biggest problem we had is that we did not understand the jurisdiction of the International Criminal Court. In one way or the other, we would stray into areas we did not properly understand; sometimes doing attributions that should not have been pegged on the work of the ICC. Sometimes we have a problem of running our own personal biases as analysis... I think that is a big problem on our side, as journalists.

All interviewees seemed to agree that the overtures for peace and the unprecedented lull in the fighting seemed to have taken the media and their audiences by surprise. This "accident", as Respondent 4 insistently called it, provided the impetus for the journalists to prefer more content on peace than that on issues of justice. Respondent 4 added pointedly: "When the commanders of the LRA started to interface with Ugandans through the media, the reality of peace became ever more evident. This is how issues of peace really came back on the media agenda", ahead of issues of justice. The progressively endearing issue of peace, perhaps unconsciously, allowed the media to overrate the role of the ICC in the huge, complex situation in Northern Uganda; this reality was represented in the content on justice/victims' issues.

Despite the dominance of content that the media considered propeace, some stories carried reminders that after peace, matters of justice required serious attention as well. Indeed, Respondent 6 confirmed that the reason behind this rationale in the media was that: ...much as peace must return to the North, there must accountability. We felt that there must be a balance: these people have committed crimes and they must not be allowed to go scot free. While peace returns to the North, there must be accountability for the crimes committed. As a newspaper, we have been toeing that line. We support the actions of the international justice system because this could help to curb commission of more crimes.

Therefore, within the $16.57 \%$ of space accounted for by justice/ victims issues in stories in 2007, the message on the need for accountability from the negotiating parties, especially the LRA, was delivered too, albeit in receding quantities.
One of the notions that cut across all interviewees was the everpresent sense of mutual dependence - or "media-ocracy" - as criticised by Schechter [10]. This relationship allowed the negotiating parties to offer journalists access to information as a bargain for self-censorship on issues regarded sensitive. As Respondent 5 recalled, the LRA created an atmosphere of unease around journalists in order to soften their work ethic by, for instance, alleging that they were part and parcel of the government negotiating team. The respondent recalls:

When I went to Juba, South Sudan] to cover the peace talks, I started off from the negatives. I was operating from an intricate position. So, in my reportage of the peace talks, I shied away from doing news analyses because analyses which seemed to expose LRA's problems would have locked me out of the main players in the peace process. Believe me or not, the LRA would not have talked to me if I had written analyses which seemed to expose their problems. I had to maintain some sort of balance (Interviewed in Kampala on 19 March 2008).

Tactically, the decision to endear sources within the negotiating teams more than the claims under investigation, or still, the preference to offer sources mainstream newspaper platforms that allowed to elevate their own public profiles without asking the tough questions seemed out of step with the style journalism that the print media claims to practice.

On the other hand, the role of government in defining the content published in the mainstream newspapers was not as extreme as been had been hypothesised. There was no evidence to indicate any censorship or direct manipulation by government of The New Vision, which is published by a company where government still owns majority shares, or Daily Monitor, an independent, private-owned newspaper. Indeed, Respondent 7 passionately agreed that the claims made by political actors about the peace process during 2007 were meant to keep the peace process on course. However, the respondent cautions, this was more of the government's policy-and its claims-makers-rather than an agreed policy of the news media. Respondent 7 continued to state thus:

The majority of stories which have been coming out have been those which are inclined to facilitate this peace process. The key actors in this process have tended to downplay things. For instance, both the LRA and the government agreed that the LRA should assemble before even the talks proceeded any further. But the government has not made noise about these people's failure to assemble.

Therefore, it should not be our part to say: "Government, why do you proceed with the talks when these people have not lived by what they've undertaken to do?" The government side has continued to downplay that breach (Interviewed in Kampala on 21 March 2008).

This analogy suggests that the media did not position itself to boldly set the agenda of the peace process. Rather, there was an apparent desire by the negotiating parties to use the media as means to gauge what either parties were up to, a reality that ultimately forced the media to exercise considerable caution in the manner they chose content on the ongoing peace process.

\section{Conclusion}

It is important to remind ourselves that The New Vision and Daily Monitor were chosen because they were the biggest mainstream dailies in Uganda at the time of the research. In addition, they both managed to assign some of their most senior and experienced journalists to cover and edit stories on the peace process in Juba, South Sudan; an expensive endeavour that the smaller news media could hardly afford. 
Several possible conclusions could be derived from the findings and discussion.

In the first place, claims from the political actors representing the Government of Uganda were prominent in terms of space offered to content, suggesting dominance of official claims over any other claims published in the period in question. However, it is also correct to note that during 2007, the mainstream media published more claims from groups that aggressively pursued proactive approaches to the media. The LRA, to mention one important group, managed to account for 9.26\% of space that both Daily Monitor and The New vision utilised for peace issues in 2007-in close competition with the amount of space utilised for political actors' claims-because of the groups' aggressive pursuit of the media. This was in direct contrast with almost 20 years of near-total absence of the LRA's message in the local and international media. On the contrary, major players like the religious and cultural leaders, the UN and IDP camp leaders, who had always advocated for a peaceful settlement of the conflict in Northern Uganda, through the media, only enjoyed a miserly $9.18 \%$ of content space altogether. In the latter example, the assertion that journalists were predictably reliant on the elite [2] and aggressive for news, was clearly reflected in the thematic representation of claims. It is not absolutely clear whether financial resource constraints were the only major factor that confined mainstream media in Uganda to relying on sources that were easily accessible. What seems clearer is the fact that mainstream media tended to offer more space to players with proactive media tactics. It is safe to reconfirm the argument of Mwesige [3] that there continues to be a discrepancy between the values Ugandan journalists endorse and those that they actually espouse. All journalists interviewed claimed that mainstream media played a major 'advocacy' role as a voice for

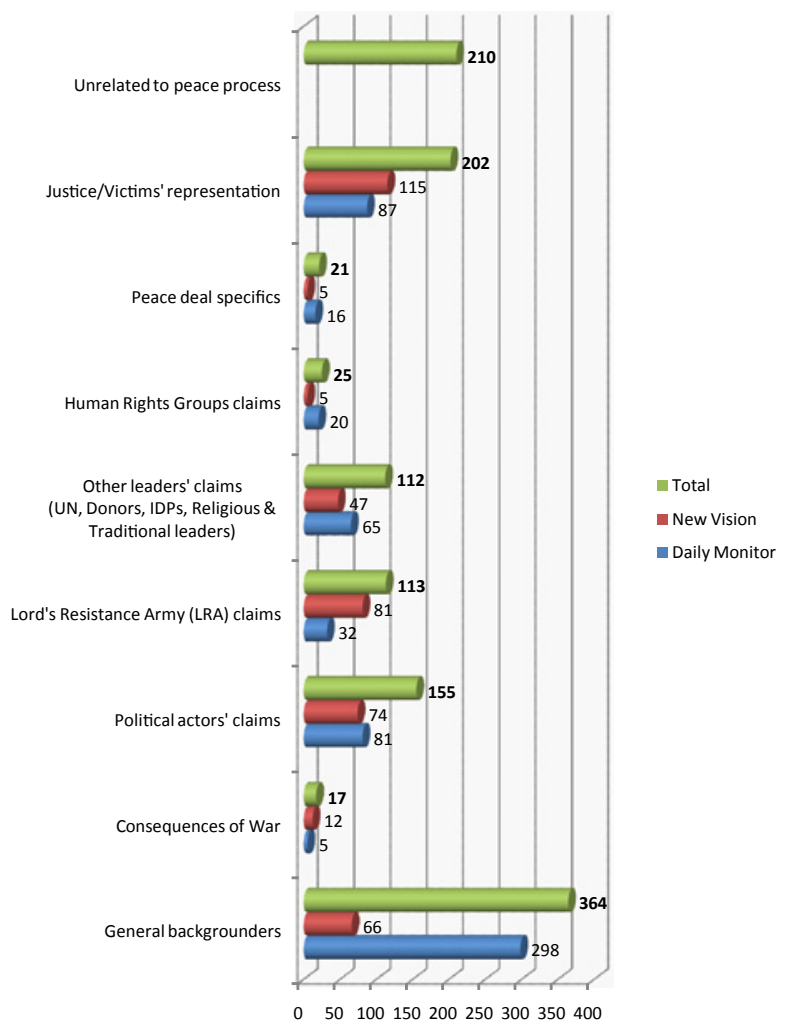

Figure 4: Thematic Totals of Paragraphs Analysed $=1,219$. the voiceless (Interviews in Kampala in March 2008). However, the content analysed does not suggest any obvious desire to provide space for the voiceless people in Northern Uganda as a platform to relay their grievances.

The overall coverage of the peace process was in tandem with the activities of the negotiation teams, either at the venue of the talks in Juba, South Sudan, or in Uganda, especially the capital Kampala. The quarterly distribution of stories (in Chapter 4, Figure 4) points to a progressive increase in the number of stories over the year in semblance with the variation of activities of the negotiating teams. There was, therefore, little or no initiative for media houses to seek to derive stories from other important quarters like the human rights groups, the internally displaced people, as well as the cultural and traditional leaders in the complete absence of claims from the two main actors in the peace negotiations: the Government of Uganda and the Lord's Resistance Army.

An apparent desire by the media to select content in manner that posed less danger to the maintenance of favourable relationships with their news sources can be inferred. During peace process, in an apparent application of tactics from the annals of peace journalism, efforts were made to curtail any discomfort arising from news content about the negotiating parties. To some extent, this approach seems to conform to the hypothesis that coverage of the peace process was manipulated to suit the agendas of negotiating parties. Importantly, however, it is clear that manipulation was not widespread. In circumstances where manipulation occurred, it was not a tactic used only by the negotiating parties. The media too had stints at manipulation through 'trading' some exclusive pieces of information they had obtained from one party to negotiate the surrender of information that would have otherwise remained outside their ambit.

A more extensive research effort could help to determine whether the tactics used by the media to gather information and report peace issues in Uganda conforms to the ethos of peace journalism or whether such practices are only utilised for the convenience they provide to journalists and their media houses in the gathering, writing, editing and reporting processes.

\section{References}

1. International Criminal Court (2008) About the Court' and 'Situations and Cases' cited on $3^{\text {rd }}$ May 2008.

2. Lee ST, Maslog CC (2005) War or Peace Journalism? Asian Newspaper Coverage of Conflicts. J Comm 55: 311-329.

3. Tehranian M (2002) Peace Journalism: Negotiating Global Media Ethics. Harv Int J Press-Pol 7: 58-83.

4. Hanitzsch T (2004) Journalists as Peacekeeping Force? Peace journalism and mass communication theory. Journalism Studies 5: 483-495.

5. http://allafrica.com

6. Dearing JW, Rogers EM (1996) Communication concepts: Agenda-setting Sage Publications, Thousand Oaks, London, UK.

7. Deacon D, Murdock G, Pickering M, Golding P (2007) Researching Communications: A Practical Guide to Methods in Media and Cultural Analysis. Hodder Arnold, London, UK.

8. Firmstone J, Statham P (2007) Mediated debate about the EU and ratification of the European Constitution in the British Sphere. European Political Commission Working Paper Series.

9. Mwesige PG (2004) Disseminator, Associates and Watchdogs: A Profile of Ugandan Journalists in the New Millennium. Journalism 5: 69-96.

10. Schechter D (2004) Slaying the Media Beast: The Media Channel as an Act of Personal Responsibility and Political Mission. International News in the 21st Century, London. 